\title{
Vegetations as Beach Protection: Simulations of Root Protection Mechanism Against Abrasion
}

\author{
Abdul Hakam", Bambang Istijono", Taufika Ophiyandri ${ }^{\#}$ \\ \# Civil Eng. Department, Andalas University, L Manis, Padang 25163, Indonesia \\ E-mail: bistijono1452@yahoo.co.id
}

\begin{abstract}
Beach abrasion is one of the national disasters that concern the Indonesian government. This disaster has resulted in adverse coastline changes in West Sumatra Province. The mainland area has been lost for hundreds meters due to abrasion. A field study has been conducted and found that beach without vegetations is very vulnerable to abrasion than the beach with vegetations. In some place, abrasion protection has been done by using hard structures but this way is not natural and attractive. A field investigation also found that several types of endemic beach vegetation in West Sumatra can live for decades till now. This condition shows that beach vegetations can be used for beach protection purposes against abrasion. This study describes the mechanism of vegetation root in protecting beaches against abrasion using numerical simulation. The data for simulation are obtained from laboratory tests of beach sands, In the numerical simulation, the beach sand is considered as geo-material that follows MohrCoulomb's constitutive law while the roots are modelled as geo-synthetic elements that can only resist the tension forces. There are three conditions to be considered in the numerical models. The first model: beach without any roots, the second one: roots under the ground surface and The third model: roots reach the ground surface. Those three models are analyzed separately using the same dimensions and parameters. The simulation results show that vegetation roots give the unity effect to the surrounding sand into a large mass. This unified soil mass that come down into the bottom provides mechanical resistance against the pull force. The simulation results explain the root mechanism of vegetation in protecting beach against of abrasion.
\end{abstract}

Keywords - abrasion; protection; vegetation; numerical analysis; west sumatra beach.

\section{INTRODUCTION}

Beach abrasion due to the influence of ocean waves can cause damage to public facilities and the environment. Beach abrasion essentially is a coastal dynamics influenced by seawater waves. Abrasion is part of the phenomenon of erosion and sedimentation cycles along the coastline. Abrasion in the developed area can cause many disadvantages such as cutting the accesses, destruction of houses and even the loss of such a beautiful sandy beach (Fig. 1). Beach protection from sea waves can be done by providing a engineering construction that can be used for energy generation as well [1]. However, building such wave protector to prevent abrasion could not restore back the lost of sandy beaches. The breakwater construction also causes the loss of beautiful sandy beaches (Fig. 2). With so many losses due to abrasion, the Indonesian government has included this natural phenomenon into one of disaster that needs to be managed [2].

Damage of beaches due to erosion or abrasion become a matter of concern to researchers since decades. Researches on coastal abrasion become excessive by linking up to the issue of global warming. Zhang et al in 2004 [3] have summarized a number of reports from the 19th to the 20th centuries on relationship of sea levels and coastal damage. This study is conducted by considering the thought of the effects of global warming on the damage on beaches. From the study it was found that the damage to the beaches has been doubled with the rate of actually sea level rise. This study notified that with the global warming scenario, the coastal abrasion problems that already look severe in the 20th century will be worse in the next century. The other studies concerned the changes in the coastal environment due to land use [4] and global warming [5].

Many beaches in the past are in critical condition due to abrasion as reported in Malaysia [6]. Recently, there are beaches along West Sumatra coastline also have been reported in critical condition due to abrasion [7]. The real actions are required for protecting those beaches from abrasion. However, unsuitable abrasion protection which is not natural will result bad effect to the environment [8]. The artificial beachrock made of sand solidification may be a prospects of beach environmental protection [9]. The other promising methods by using vegetations for coastal protection also has been studied [10]. The beaches are place 
where many [11] communities live and depend on, then their preservation needs to be protected.

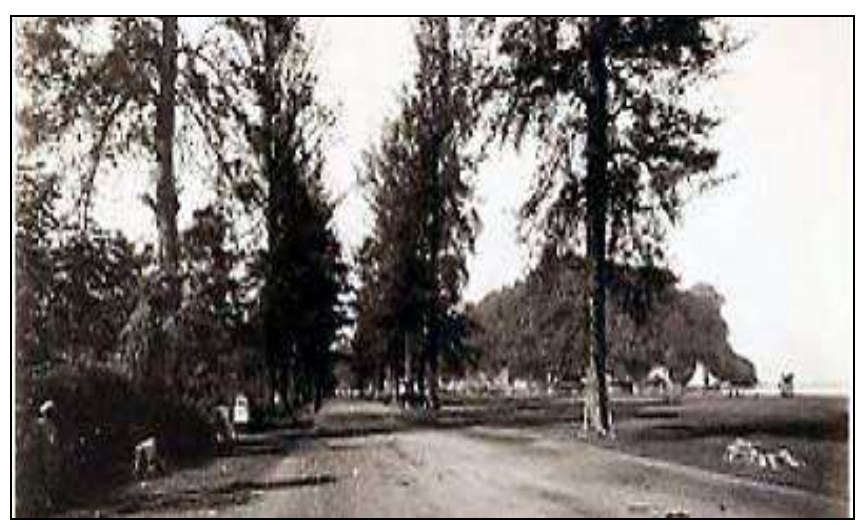

Fig. 1. Padang Beach in 1890 [12]

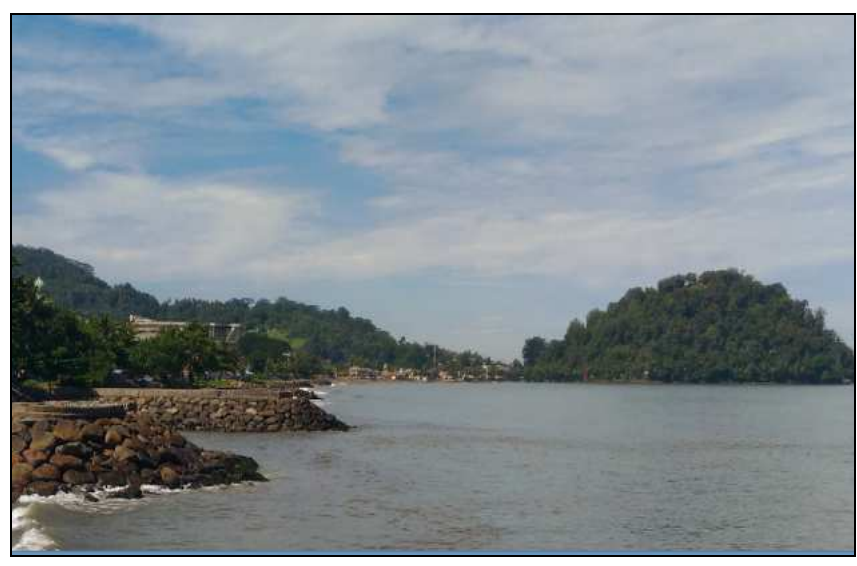

Fig. 2. The missing sandy beach in Padang

Abrasion protection has been done by using hard structures, but this eliminates the natural and not beautiful conditions. Dugan et al. in 2008 [8] has conducted a study of the ecological impact on habitat loss due to the presence of hard protective structures along the coastline. Their study found surprising results in the drop off the number of seagulls and other seabirds, who like to perch on the beach. With the many of needs on the coastline the actions are required for beach protection from abrasion. The study concludes the importance of further studies on natural coastal protection that involves the environmental management and preservation.

To protect beaches from abrasion it is necessary to prevent the sea waves from taking the beach sand particles away from their original place. Abrasion can be prevented by constructing the energy breaker of the waves that may cause the damage. In addition it can also be done by covering the ground such that the seawater cannot transport them away. However those ways are not natural and less beautiful. The more natural way is to plant a protective vegetation on beaches. The results of field investigations along the coast in West Sumatra Province found that some kind of marine vegetation can withstand against abrasion or sea erosion. The types of vegetation found to wave-resistant include sea pine, coconut, mangroves and locally trees known as pinago and ketaping. A numerical simulation modelling was conducted in order to understand the way of those vegetation roots in protecting beaches from abrasion. The simulations are purposed to demonstrate the root mechanism in protecting the sandy beaches against seawater erosion.

\section{MATERIAL AND MethoD}

Field investigation results empirically prove that marine vegetations are able to withstand against abrasion. It is found that the abrasion area will be terminated in the zone where there is a vegetation on it (Fig. 3). While in areas that are not planted, seawater took sand away till several meters into the mainland. Roots are a most important part of vegetation to protect land from abrasion. The marine plant roots can grow to creep outward from the ground surface (Fig. 4).

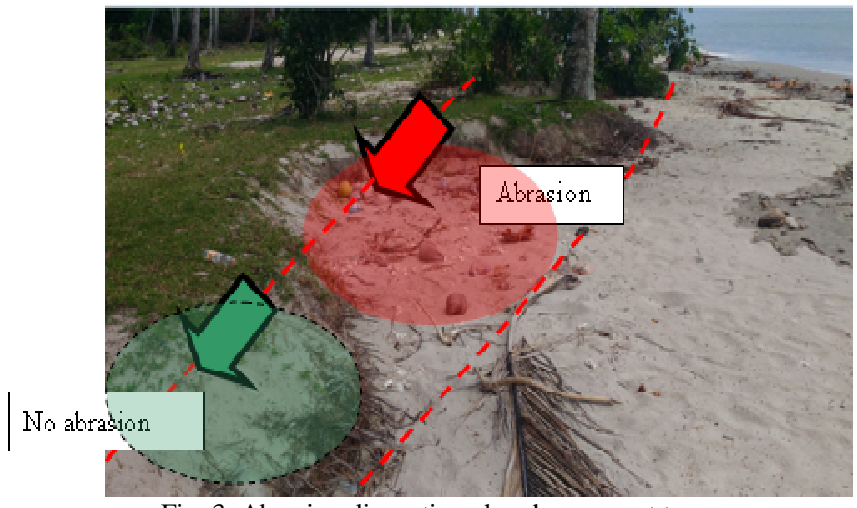

Fig. 3. Abrasion discontinued under coconut tree

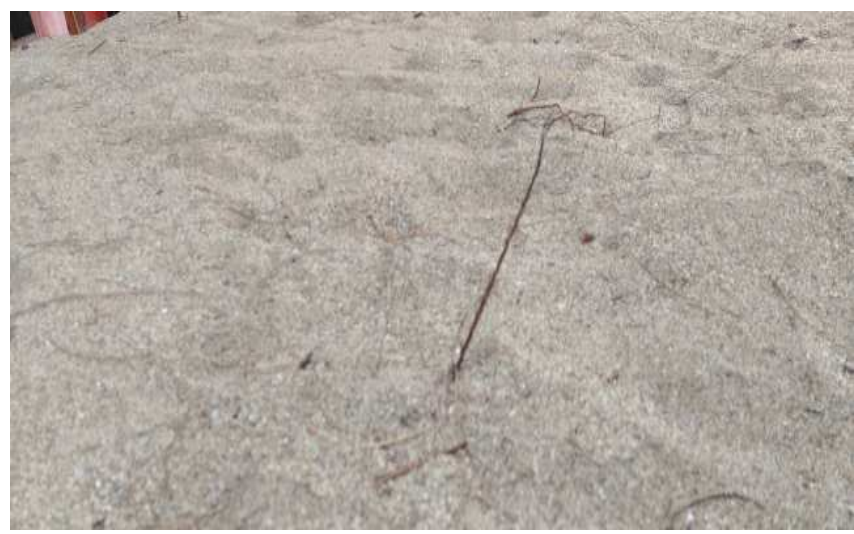

Fig. 4. The sea pine roots grow out of the ground surface

The marine vegetation roots can go up to 4 meters from the main wood. The maximum distance of the root extension depends on the soil, planting way and species. For the vegetation where its soil sides have been removed by abrasion, it is found that the roots go only up to about 2.5 meters (Fig. 5). This is caused the roots have lost the soil where they need to grow for, are destroyed and taken by the seawater. In order to play as an abrasion protector, the roots and the soil has to take part in symbiotic mutualism.

Density of marine vegetation is also a factor that affects resistance against abrasion. The closer the spacing, the greater the ability to resist abrasion. The spacing which is shorter than maximum the root can go, will cause the roots cross each other in the form of organic net. This root net will keep the surrounding soil from transported by seawater. 
While single standing plants with roots are not interconnected, more easily overturned by seawater.

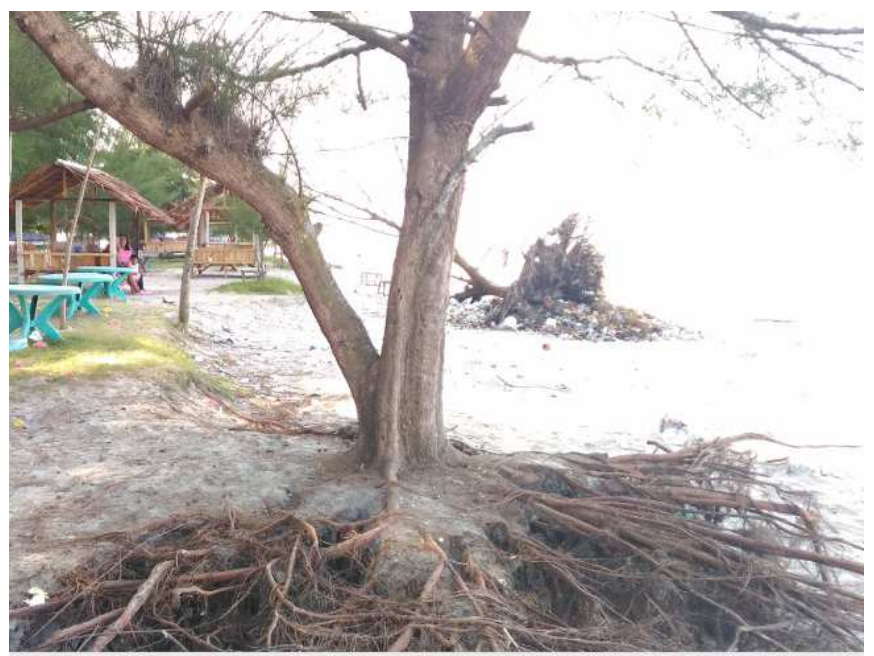

Fig. 5. The root with scoured surrounding soil

In order to understand the root mechanism for protecting the beach from abrasion, the numerical modelling involving root and soil interaction to the pulling effect of seawater. This numerical simulation is completed using the finite element model. The root mechanism for beach protection models are conducted in three conditions that are:

1. Beach without any roots

2. Roots under the ground surface

3 . Roots reach the ground surface

Those three models are analysed separately but with the same dimensions and other values. The movement of seawater away from the coastline is modelled by pulling effect to the sand soil. Each model only considers the pulling effect, since the soil on the beach consists of sand with a very small tensile resistance.

TABLE I

ENGINEERING PARAMETERS OF THE BEACH SAND

\begin{tabular}{|l|l|l|l|}
\hline No. & Parameters & Value & Unit \\
\hline 1 & Dry density & 12.37 & $\mathrm{kN} / \mathrm{m}^{3}$ \\
2 & Wet density & 13.84 & $\mathrm{kN} / \mathrm{m}^{3}$ \\
3 & Saturated density & 16.36 & $\mathrm{kN} / \mathrm{m}^{3}$ \\
4 & Cohesion strength & 0.94 & $\mathrm{kN} / \mathrm{m}^{2}$ \\
5 & Internal friction angle & 32.3 & $\mathrm{deg}$. \\
6 & Modulus of elasticity & 52352 & $\mathrm{kN} / \mathrm{m}^{2}$ \\
7 & Poisson's ratio & 0.25 & - \\
\hline
\end{tabular}

The root strength for the analysis purposes is taken based on the wood strength of $30,000 \mathrm{kN} / \mathrm{m}^{2}$ and a modulus of elasticity of $6.0 \times 106 \mathrm{kN} / \mathrm{m}^{2}$. The soil mechanical parameters used for simulation are obtained from beach sand tests. The sand soil strength parameters were obtained through direct shear testing (Fig. 6). The strength parameters of the soil are following the Mohr-Coulomb failure criteria, that gave the internal shear angle of 32.3 degree and cohesive coefficient of $0.0084 \mathrm{~kg} / \mathrm{cm}^{2}$. The other parameters obtained from the test results are shown in Table 1.

\section{RESULTS AND DISCUSSION}

The results of the numerical simulation of root and soil interaction are presented here. In the finite element simulations, the beach sand is considered as geo-material that follows the Mohr-Coulomb's constitutive law. While the roots are modelled as geo-synthetic elements that can only resist the tension forces. In order to understand the effect of roots on abrasion, the analyses are then carried out in three conditions such as the same geometric and loads (Fig. 7). The pulling effect of seawater is modelled as the prescribed displacement on the sand surface for all conditions. Every model is given the same a unit pulling force, which can give the same results in terms of displacement. However, every model is supposed to have different failure mechanism and stress results.

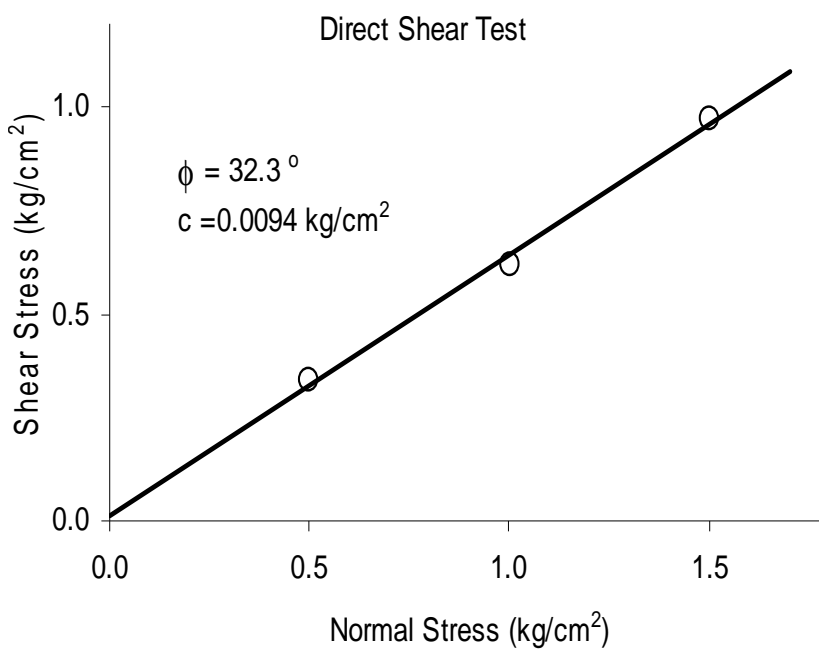

Fig. 6. Direct shear test results of beach sand samples

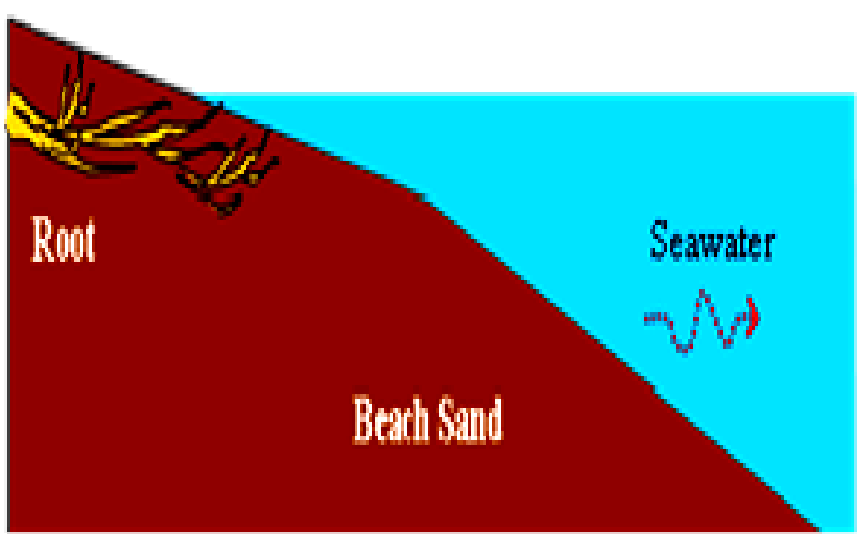

a. Statigraphy model 


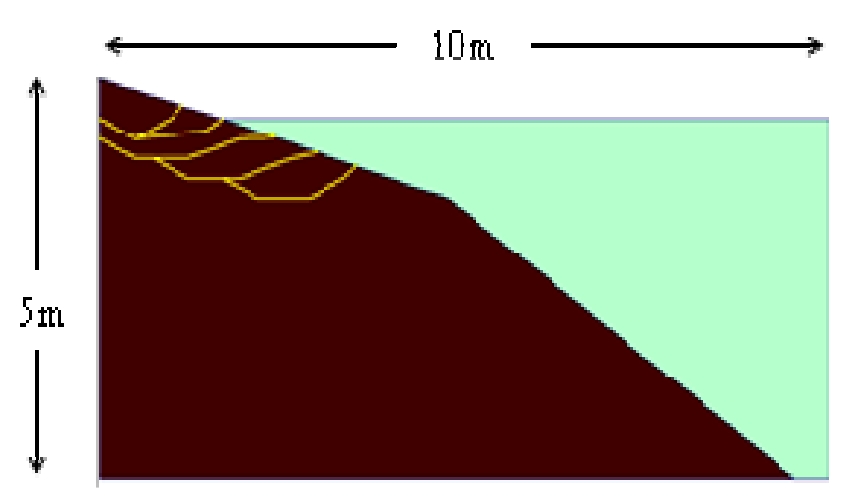

b. Simulation model

Fig. 7. Simulation of sand-roots interaction model

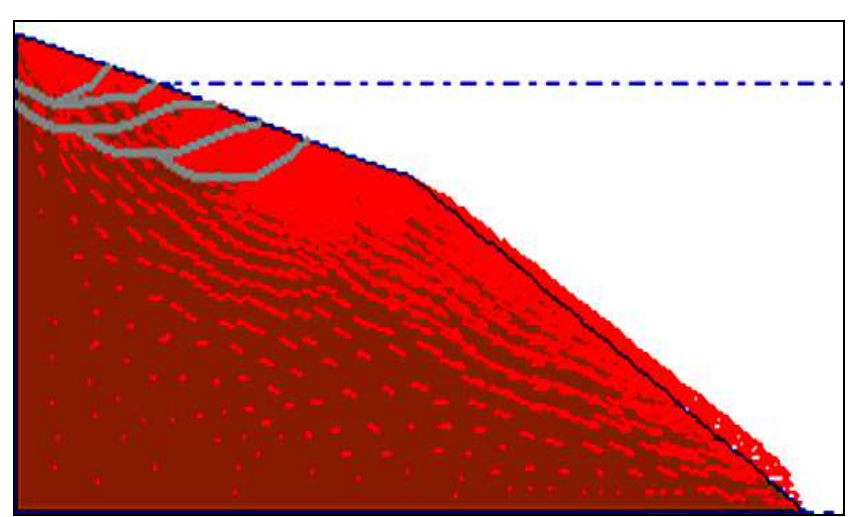

a. No root

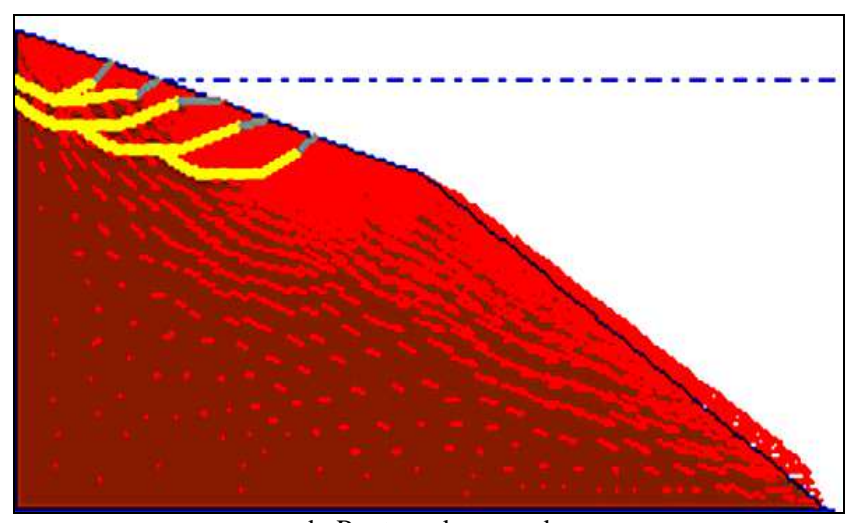

b. Roots underground

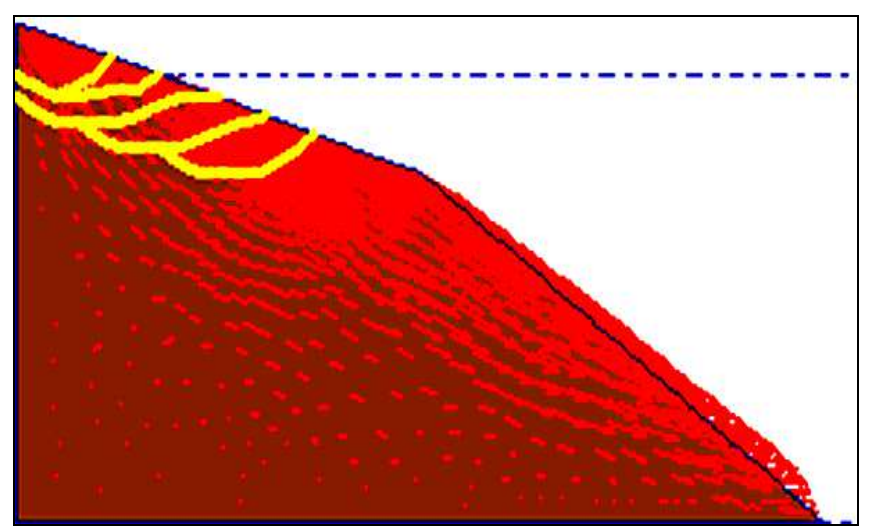

c. Roots up the surface

Fig. 8. The collapse model of sandy beach

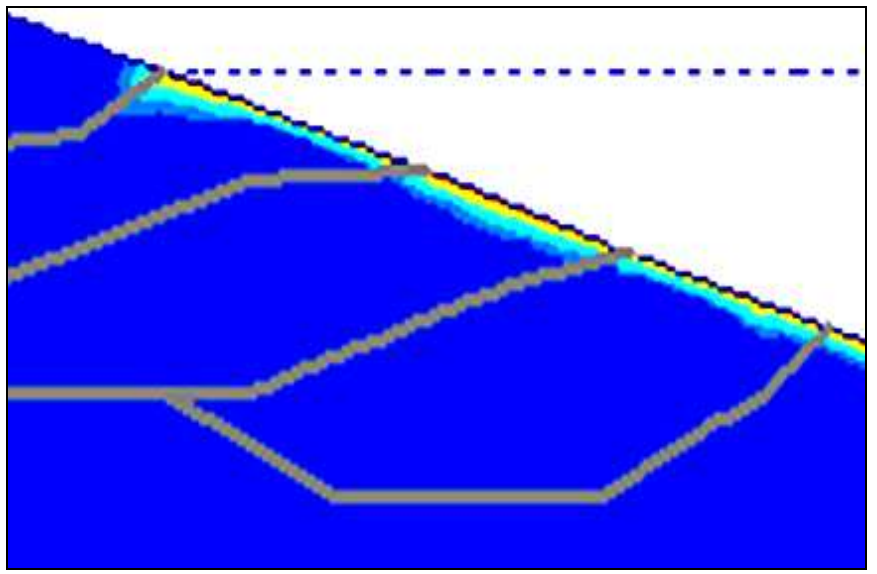

a. No root

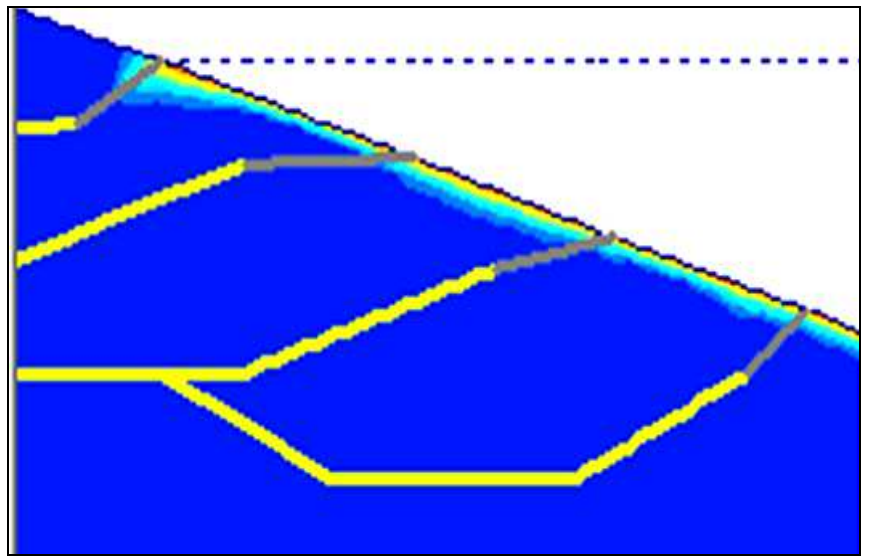

b. Roots underground

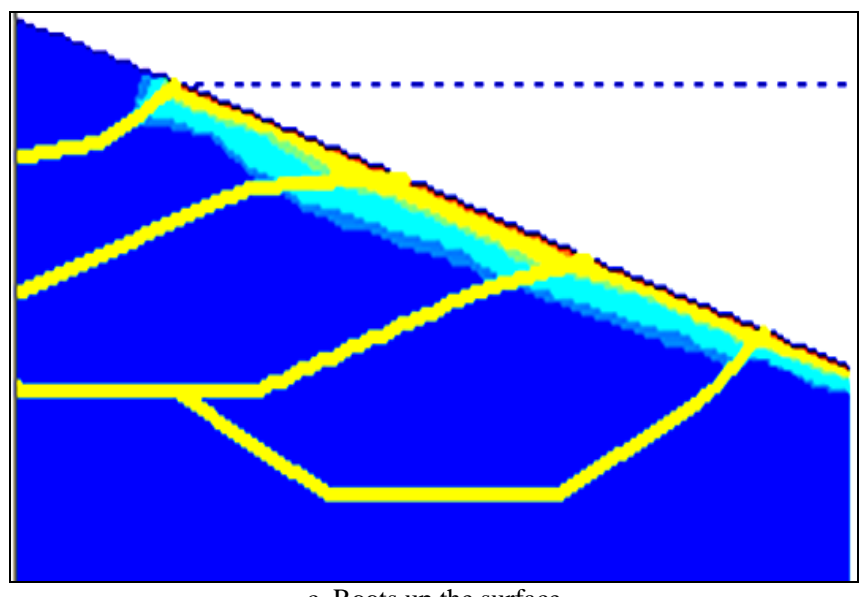

c. Roots up the surface

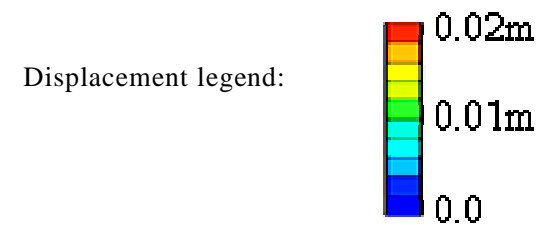

Fig. 9. Total displacement due to water suction 


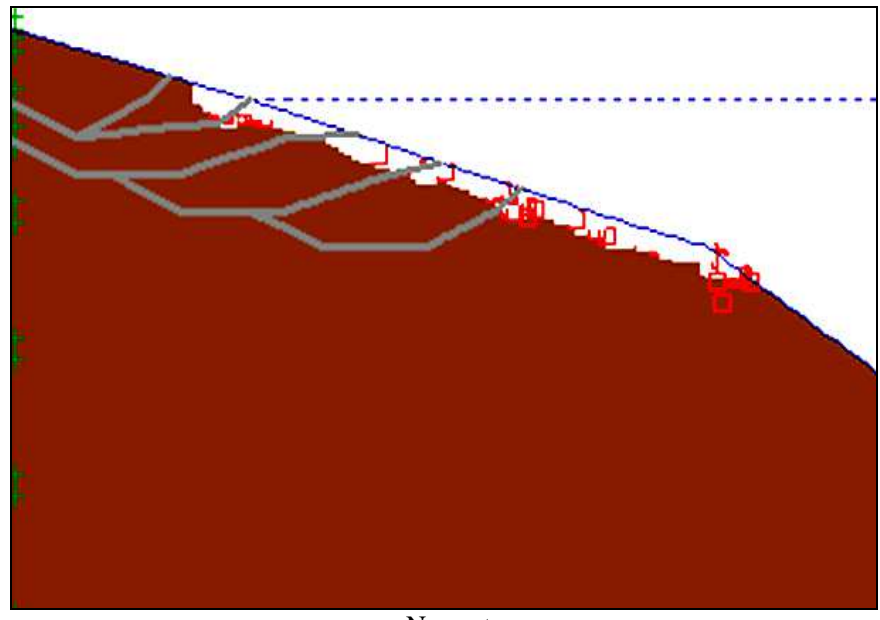

a. No root

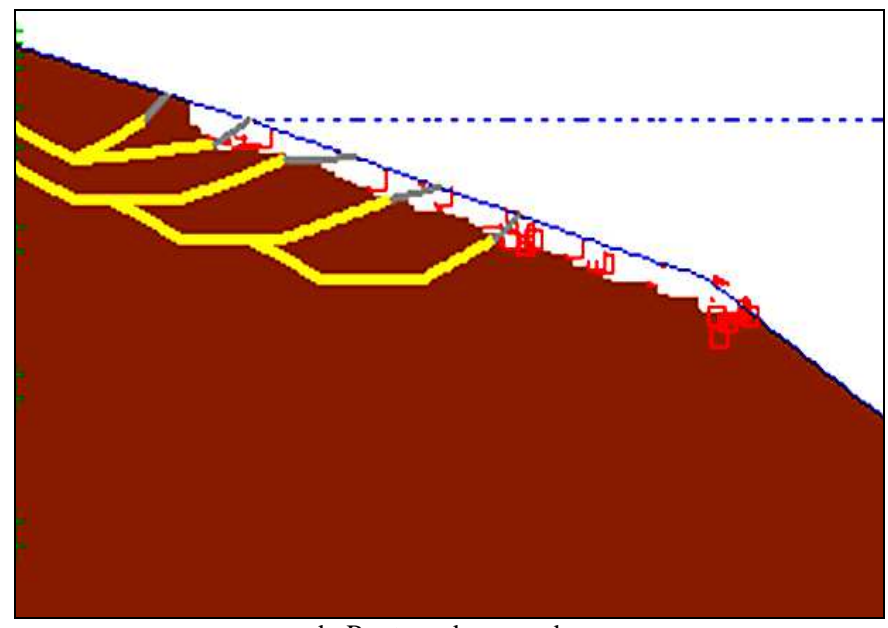

b. Roots underground

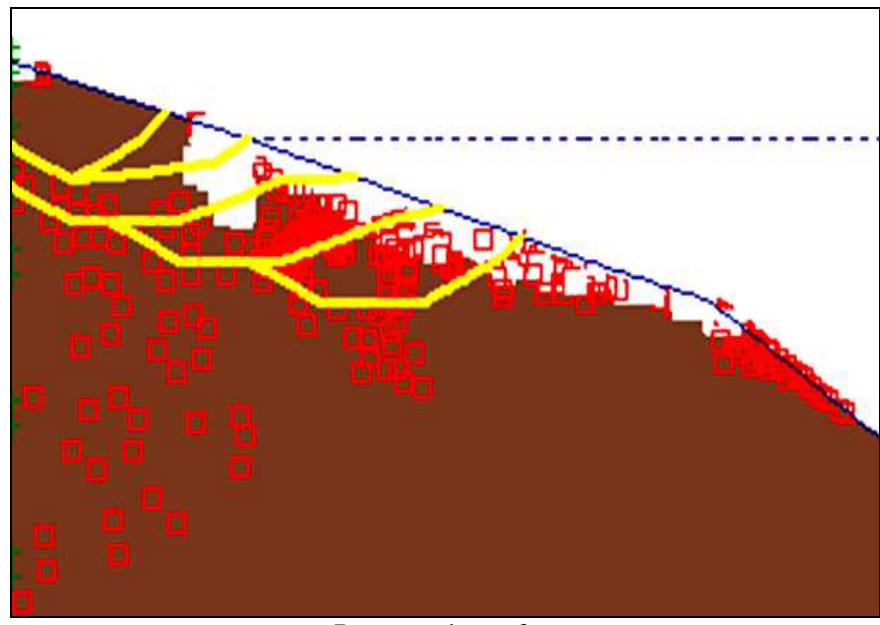

c. Roots up the surface

Note: Mohr-Coulomb limit

Tension element

Fig. 10. Soil masses that affected by abrasion

First, the simulations of those conditions are conducted to give static safety factors. The static safety factor for those model are about the same that is 1.49 . The failure patterns of the models are also similar (Fig. 8). The simulations results in the form of displacement indicate the soil element pulled by the water shown in Fig. 9. In a situation where there is no roots, the sands pulled by seawater is closed on the surface only. The same thing happens in conditions where the roots do not reach the ground surface. Both results show that in absence of the root on the soil surface, the soil particle will be easily transported by water. However, in the condition where the roots reach up the surface, the area of soil that pulled by water goes deeper. It seem that the soil masses affected by puling water are going deeper. It indicates the roots that reach the surface will provide the unification effect to the surrounding sand.

The figures shows in Fig.9 can be described that the soil mass that are pulled by the seawater in the same displacement value. The existence of the root will make the soil mass pulled by the water become bigger. It the force needed to move the soil mass is equal to the soil weight, then the force needed to move the soil mass from its original place is bigger when the soil hold each other than its in separated condition.

The areas of soil that are affected by the water suction are shown as elements in the tension state in Fig. 10. This results also show the soil mass that works to resist pulling until its strength limit. For the models where there is no roots and roots do not reach the surface, the simulation results show that only the soils on the surface are affected by the water. The results indicate that the soils are in absence of interconnection each others, so they are easily taken away by the seawater. It is also caused by the sand has very little cohesion strength. When the root reaches up to the surface, the soil mass affected by pulling are becoming bigger. It can be seen also that the soil mass in tension state comes into the deeper into the ground. It means that the suction effect by water is held by the soil mass until the deeper ground. This results shows that the roots preserves the unity effect to the soil mass in certain numbers in resist against abrasion. The simulation results indicate that in situations where the roots spread up to the surface, the beach has better protection against abrasion.

\section{CONCLUSIONS}

Abrasion is one of national disasters that has resulted in disadvantage coastline changes. The impact of abrasion that has wiped out the mainland till hundreds meters can be reduced by planting vegetation along the affected coastline. Abrasion protection can also be done by constructing hard structures but this unnatural ways have less beautiful. Based on the field investigation that has been done there are several marine vegetation that can be grow up to decades. The field study also found that the marine vegetations were effectively able to protect against abrasion.

This study has described the mechanism of vegetation root in protecting beaches against abrasion using numerical simulation. The beach sand samples have been taken and tested to obtain the parameters for numerical simulation. The beach sand is considered as geo-material that follows MohrCoulomb's constitutive law while the roots are modeled as geo-synthetic elements that can only resist the tension forces. There are three conditions to be considered in the numerical models. First model: beach without any roots, Second: roots under the ground surface and Third one: roots reach the ground surface. Those three models are analyzed separately using the same dimensions and parameters. 
Based on the finite element analyses results of the models, it can be explained that the roots play a role to unify the soil mass that holds each other to prevent abrasion. This unified soil mass then goes to the lower soil layer and provides increase the resistance against the pull up force. This phenomena are shown by comparing the numerical results for the third models to the others. Furthermore, it also increases the overall beach resistance against the abrasion. While in the absence of vegetations the beach is very vulnerable to seawater abrasion.

\section{ACKNOWLEDGMENT}

This research is funded by Andalas University under Research Grant No 68/UN.16.17/PP.HGB/LPPM/ 2017. Special thanks to our colleagues Dr. Helmy Darjanto and Dr. Mokhammad Farid Ma'ruf who have helped in the process of finite element simulation.

\section{REFERENCES}

[1] Empung, N. Hiron and A. Chobir, Oscillating Water Column (OWE) Building Performance Analysis As Beach Abrasion Reducing, IIOABJ Vol. 7, Suppl. 1, pp. 515-520, 2016

[2] BNPB, The Regulation of the Head of National Disaster Management Agency No. 07/2012: Guidelines for Data Management and Disaster Information in Indonesia (in Bahasa: Peraturan Kepala Badan Nasional Penanggulangan Bencana Nomor 07 Tahun 2012 Tentang Pedoman Pengelolaan Data dan Informasi Bencana Indonesia), Jakarta 2012

[3] K. Zhang, B.C. Douglas and S.P. Leatherman, , Global Warming and Coastal Erosion, Climatic Change, 64: 41, May 2004
[4] Y.W. Soedarto, , L.Hanum, , M.S.Lestari, , Analysis and Identification of Landuse on the Coastal Environment of South Sumatra using GIS, International Journal on Advanced Science, Engineering and Information Technology, Vol. 7 (2017) No. 3, pages: 785-791, 20 July 2017

[5] D. Yuliadi, Eriyatno, M. Yanuar, J. Purwanto, I W.Nurjaya, Socio Economical Impact Analysis and Adaptation Strategy for Coastal Flooding (Case Study on North Jakarta Region), International Journal on Advanced Science, Engineering and Information $\mathrm{T}$ echnology, Vol. 6 (2016) No. 3, pages: 390-393, 20 July 2017

[6] Balai Wilayah Sungai Sumatera (BWSS) V, Project Report: Identification of Critical Coast in West Sumatera Province (in bahasa: Identifikasi Pantai Kritis di Propinsi Sumatera Barat), Padang, 2009

[7] M.A. Othman, Value of mangroves in coastal protection, Hydrobiologia 285: 277-282, 1994.

[8] E.D. Jenifer, D.M. Hubbard, I.F. Rodil, D.L. Revell and S. Schroeter, Ecological effects of coastal armoring on sandy beaches, Marine Ecology 29, Suppl. 1, pp. 160-170, 2008

[9] Md N.H. Khan , T. Danjo and S. Kawasaki, Artificial Beachrock Formation Through Sand Solidification Towards The Inhibit Of Coastal Erosion In Bangladesh. Int. J. of GEOMATE, 9(2), pp.1528-1533, Dec., 2015

[10] R. A.Feagin, J. Figlus, J.C. Zinnert, J. Sigren, M.L. Martínez, R. Silva, R., and G. Carter. Going with the flow or against the grain? The promise of vegetation for protecting beaches, dunes, and barrier islands from erosion, Frontiers in Ecology and the Environment, 13(4), pp. 203-210, 2015

[11] E. Arthur B, F. Vladimir R, L.M. and Teresa B, Socio-Ecological and Livelihood Assessment of Selected Coastal Areas in Sorsogon, Philippines, International Journal on Advanced Science, Engineering and Information T echnology, Vol. 5 (2015) No. 4, pages:339-343

[12] Ohgituto, Minangkabau Tempo Doeloe \#1 - Padang, http://ohgituto.blogspot.co.id, 27 Nov. 2012 